\title{
Influence of culture conditions on expansion and re-differentiation of chondrocytes from horses of different ages
}

\author{
Cecile Werren', Jose Diaz-Romero², Walter Brehm and Dobrila Nesic \\ Equine Clinic, VetSuisse Faculty ${ }^{1}$, University Bern, Bern, Switzerland and Osteoarticular Research Group, Institute of Pathology ${ }^{2}$, University of Bern, Bern, \\ Switzerland
}

\begin{abstract}
Summary
To evaluate the influence of types of sera and the donors age on proliferation and re-differentiation capacities of equine chondrocytes, cartilage tissue from 10 horses was obtained in the age range 2.5 to 19 years. Chondrocytes were isolated from the fetlock- joints and expanded in media containing different types of sera: fetal calf serum (FCS), fetal equine serum (FES), adult equine serum (AES) and autologous serum. Cells were expanded in monolayers at low and high seeding densities. Chondrocytes re-differentiation capacities were assessed in micromass pellet cultures after 4 weeks of incubation in chondrogenic medium supplemented with or without $5 \mathrm{ng} / \mathrm{ml}$ TGF $\beta 1$. The neocartilagineous tissue formation was evaluated through proteoglycan and collagen type II deposition, and Berne score visual evaluation system. Results showed that the low seeding density allows for higher proliferation rates in FCS, FES and AES. In addition chondrocytes from younger horses proliferate faster independently of the serum type. Re-differentiation capacities are influenced by the animals age, type of serum during expansion, and the presence of TGF $\beta 1$ in pellet cultures. Cells from young horses appear to produce better neocartilage upon expansion in autologous serum, while cells from older horses re-differentiated better upon expansion in FCS. The expansion conditions of potential clinical relevance include the correct choice of sera according to the age of horse during monolayer culture for better subsequent re-differentiation and lower seeding densities allowing for smaller biopsy sampling and therefore less injury to the donor site.
\end{abstract}

Keywords: cartilage repair, chondrocyłe cell culture and biology, differentiation, tissue engineering, cartilage, bone

\section{Einfluss von Kultivierungsbedingungen auf die Vermehrung und die Redifferenzierung von Chondrozyten von Pferden verschiedenen Alters}

Um den Einfluss von verschiedenen Seren, des Alters des Knorpelspenders und der Redifferenzierungs-Kapazität von Pferdechondrozyten zu beobachten, wurde von 10 Pferden im Alter zwischen 2.5 und 19 Jahren Knorpelgewebe entnommen. Knorpelzellen wurden aus Fesselgelenken isoliert und in Medien mit verschiednen Seren vermehrt: fötales Kälberserum (FCS), fötales Pferdeserum (FES), adultes Pferdeserum (AES) und autologes Serum. Zellen werden in hoher- und in tiefer Aussaatdichte in Monolayerkulturen vermehrt. Die Redifferenzierungskapazität von Pferdechondrozyten wurde in Micromasspelletkulturen, nach einer Inkubation von 4 Wochen in einem chondrogenen Medium mit oder ohne 5ng/ml TGF $\beta 1$ beurteilt. Die Bildung von Knorpelpellets wurden mit Hilfe der Deposition von Proteoglykanen und Kollagen Typ II und dem Bern Score einem visuellen Auswertungssystems bewertet. Die Resultate zeigten, dass tiefere Aussaatdichten höhere Proliferationsraten in FCS, FES und AES erlauben. Chondrozyten von jungen Pferden vermehren sich besser unabhängig vom Serum. Die Redifferenzierungs-Kapazität ist beeinflusst durch das Alter des Tieres, dem Serum während der Zellvermehrung und der Präsenz von TGF $\beta 1$ während der Kultivierung zu Pellets. Die Zellen von jungen Pferden scheinen bessere Knorpelpellets nach Vermehrung in autologem Serum zu produzieren, während Zellen von älteren Pferden sich besser redifferenzieren, nach der Vermehrung in FCS. Klinisch relevante Bedingungen sind die richtige Wahl des Serums, in Abhängigkeit des Alters des Pferdes, um anschließend eine bessere Redifferenzierung zu erreichen, sowie tiefere Aussaatdichten die die Entnahme kleinerer Biopsien erlauben und dadurch weniger Schädigung an der Entnahmestelle zur Folge haben

Schlüsselwörter: Knorpelheilung, Chondrozytenkultur, Chondrozytenbiologie, Differenzierung, Tissue Engineering, Knorpel

\section{Introduction}

Articular cartilage is a nonvascular, noninnervated tissue consisting of round chondrocytes characterized by their ability to produce high levels of collagen types II, IX, and XI and proteoglycans, the main constituents of the hyaline extracellular matrix (Mendler et al. 1989, Cremer et al. 1998). Cartilage serves as a load-bearing elastic material that is responsible for the frictionless movement of the surfaces in the articulating joints. Articular cartilage lesions are frequent and arise from trauma and/or different joint diseases as a consequence of genetic and metabolic disorders.
Due to its particular structure, hyaline cartilage has limited intrinsic reparative capacity and heals poorly (Ulrich-Vinther et al. 2003). The size, depth and site of lesion highly influence the healing process. Ultimately, defects can lead to osteoarthritis. Cartilage defects represent a challenge in equine orthopaedics, in particular for the treatment of racing and sport horses (Mcllwraith et al. 1987). Furthermore, the horse is considered as an important and relevant large animal model for cartilage repair studies due to the cartilage thickness and naturally occurring osteoarthritis, which are similar to human (Reinholz et al. 2004, Frisbie et al. 2006). 
In the past decade tissue engineering has emerged as a new therapy with the goal to provide structural and functional substitutes for damaged organs and tissues by combining cells, biomaterials and signalling molecules (Vacanti et al. 1998). Autologous chondrocyte implantation ( $\mathrm{ACl}$ ) has gained interest as a clinically applied cell based therapy for the repair of localized traumatic cartilage lesions in humans (Marlovits et al. 2006), and this procedure, following the original method [Brittberg et al. 1994), has also been tested in full thickness cartilage defects in the horse (Litzke et al. 2004). The procedure described here comprises chondrocyte isolation from biopsies taken from a low weight-bearing area of the hock, followed by cell expansion in monolayer. When a sufficient number of cells was obtained, chondrocytes were implanted into the lesion under a periosteal flap or collagen membrane. During the expansion phase in monolayer, chondrocytes alter their morphology and metabolism in a process termed de-differentiation (Schnabel et al. 2002), whereby cells gradually lose their chondrogenic "commitment" and phenotype. Recently, the production of large scaffold free cartilage constructs, after expanding equine chondrocytes in monolayer culture, has been described (Brehm et al. 2007). Therefore, a prerequisite for cell based therapies is an efficient method for the expansion of the chondrocytes. This method must support the chondrocytes' re-differentiation capacity and allow the production of extracellular martrix that is of sufficient quality to provide a functional articular joint. During the expansion phase chondrocytes must be provided with nutrients and growth factors to proliferate. Fetal calf serum (FCS) is commonly used as a supplement to the expansion medium providing growth factors, adhesion molecules, and vitamins. The exposure of cells to FCS however, has several disadvantages including possible viral or bacterial infections (Dedrick 1997) and transmission of prions (Klein and Dumble 1993). If the cells have been exposed to FCS during cultivation, the following transplantation may induce immune or local inflammatory responses (Selvaggi et al. 1997, Heiskanen et al. 2007). Therefore, the development of FCS-free culturing protocols certainly represents an advantage for future development of cellular therapies, and the use of serum-free media, allogenic, and autologous serum have being already investigated as potential alternatives for growing cells in human regenerative medicine (Stute et al. 2004, Shahdadfar et al. 2005, Tallheden et al. 2005). In addition to serum-supplementation, chondrocyte proliferation rates in monolayer culture have been shown to depend on factors such as the cell-seeding density (Mandl et al. 2004) or the age of the donor (Barbero et al. 2004). Therefore, optimizing culturing conditions for equine chondrocytes can contribute towards more efficient treatment of horse injuries in equine clinics and provide further knowledge towards development of cell based treatments in human patients. The goal of this study was to examine equine chondrocyte proliferation in xenogenic (FCS), allogenic (FES and $A E S$ ) and autologous serum regimes, under different seeding densities and with respect to horse age, and to compare their subsequent re-differentiation capacities.

\section{Materials and Methods}

\section{Cartilage sampling}

Full thickness equine articular cartilage samples were obtained from the trochlea metacarpale and from the fossa arti- cularis of the first phalanx of fetlock-joints from 10 sport horses at autopsy within 24 hours post-mortem. Cartilage samples derived from slaughtered horses, aged $4.4 \pm 2.2$ year (mean \pm SEM) for experiments 1 and $2(n=5), 8.6 \pm 2.5$ years $($ mean $\pm S E M)(n=3)$ and $19 \pm 0$ years (mean \pm SEM) $(n=2)$ for experiment 3. None of the horses was under drug treatment, had clinical history of arthritis or other pathologies affecting cartilage. The specimens appeared normal by morphological examination (no change in colour and no fibrillation). The term "young" was employed for horses below 12 years, and the term "old" for horses older than 12 years. Cartilage samples were kept in transport medium (D-MEM/F12, $100 \mathrm{U}$ penicillin/streptomycin, Life Technologies, Basel, Switzerland) for a maximum of 24 hours post sample collection and prior to further processing.

\section{Chondrocyte isolation}

Cartilage was sequentially digested with pronase and collagenase $P$ as previously described (Diaz-Romero et al. 2005). Briefly, cartilage was diced in PBS and incubated for one hour with $2.5 \mathrm{mg} / \mathrm{ml}$ pronase (Roche, Rotkreuz, Switzerland) in digestion medium $(10 \mathrm{ml}$ per gram of wet tissue): DMEM/F 12 containing $1 \mathrm{~g} / \mathrm{ml}$ bovine insulin (Life Technologies, Basel, Switzerland); 50g/ml ascorbic acid (Fluka, Buchs, Switzerland) in a shaking water bath at $37^{\circ} \mathrm{C}$. After removal of pronase and washing with PBS, digestion was continued overnight by addition of $250 \mathrm{~g} / \mathrm{ml}$ of collagenase P (Roche, Rotkreuz, Switzerland) in digestion medium $(10 \mathrm{ml} / \mathrm{g}$ of wet tissue) in a shaking water bath at $37^{\circ} \mathrm{C}$. The resulting cell suspension was filtered through a 100 m nylon cell strainer to remove debris. Cells were centrifuged (Sorvall, RT6000D; rotor $1000 \mathrm{~B}$ ) at $700 \mathrm{~g}$ for 6 minutes at $100 \mathrm{C}$, washed twice with PBS, counted, and either cryopreserved in $90 \%$ of corresponding serum and 10\% DMSO, or seeded in tissue culture flasks.

\section{Monolayer culture}

After isolation, cells were seeded for 48 hours at 65'000 cells $/ \mathrm{cm}^{2}$ to allow recovery in D-MEM/F12 containing L-glutamine and 100u penicillin/streptomycin. Medium was supplemented with 10\% of different sources of sera: fetal calf serum (HyClone, Lausanne, Switzerland), fetal equine serum (Biowest, Nuaillé, France), adult equine serum (Biowest, Nuaillé, France) or autologous serum. Chondrocytes were cultured at $37^{\circ} \mathrm{C}$ in a humidified atmosphere containing $5 \%$ $\mathrm{CO}_{2}$. After 48 hours, cells were harvested by trypsin/EDTA incubation. Trypsin activity was neutralized with the corresponding serum, and after washing and counting, cells were either cryopreserved or re-seeded in monolayer culture at two different densities: high-10'000 cells $/ \mathrm{cm}^{2}$ and low-3.333 cells $/ \mathrm{cm}^{2}$. The medium was changed the following day and then every 2-3 days. Monolayer cultures were maintained until 40 days with passaging at 10 days intervals.

\section{Preparation of autologous sera}

Autologous serum was prepared from 3 young and 2 old horses after stunning. Between 0.5 to 2 litres of blood were asep- 
tically collected from the Vena jugularis, allowed to clot for 4 hours at $4-8^{\circ} \mathrm{C}$ and centrifuged at $830 \mathrm{~g}$ for 10 minutes. The obtained supernatant was subsequently centrifuged at $1300 \mathrm{~g}$ and then at $1800 \mathrm{~g}$ each time for 10 minutes. Debris was removed by filtration through a $100 \mathrm{~m}$ nylon cell strainer. Serum was sterilized by filtering through $0.2 \mathrm{~mm}$ filter, heatinactivated by incubation at $56^{\circ} \mathrm{C}$ for 30 minutes, and aliquots were prepared and stored at $-20^{\circ} \mathrm{C}$ until further use.

\section{Pellet cultures}

Chondrogenic re-differentiation was induced in micromass pellet cultures using a defined serum-free medium as previously described (Körner et al. 2006). Cells expanded at low seeding density were harvested after 20 days in monolayer culture and resuspended in high glucose DMEM medium supplemented with ITS $+1110 \mathrm{~g} / \mathrm{ml}$ insulin, $5.5 \mathrm{~g} / \mathrm{ml}$ transferring, $5 \mathrm{ng} / \mathrm{ml}$ selenium, $0.5 \mathrm{mg} / \mathrm{ml}$ bovine serum albumin $4.7 \mathrm{~g} / \mathrm{ml}$ linoleic acid, Sigma-Aldrich, Buchs, Switzerland), 0.1 $\mathrm{mM}$ ascorbic acid, 10-7M dexamethasone and rh-TGF1 (Acrys, Hiddenhausen, Germany). $5 \times 10^{5}$ chondrocytes were placed in $15 \mathrm{ml}$ falcon tube, resuspended in $3 \mathrm{ml}$ of differentiation media and centrifuged at $300 \mathrm{~g}$ for 5 minutes at $4^{\circ} \mathrm{C}$. Pellets were incubated at $37^{\circ} \mathrm{C}$ in a humidified atmosphere containing $5 \% \mathrm{CO}_{2}$ for 4 weeks, with medium change twice weekly.

\section{Histology}

Pellets were fixed for 24 hours in $4 \%$ paraformaldehyde, embedded in paraffin and cut in $4 \mathrm{~mm}$ thick sections. Haematoxylin-eosin, Alcian blue and Safranin $\bigcirc$ staining were performed to assess cell morphology and proteoglycan synthesis. Bright field pictures were taken with Axioplan 2 microscope and Axiocam camera (Zeiss). Berne score, a visual grading system for assessment of in vitro engineered cartilageneous tissue was applied for each slide stained with Safranin$\bigcirc$ (Grogan et al. 2006). The uniformity and intensity of Safranin- $O$ staining, distance between cells versus the amount of matrix produced and cell morphology were determined. For each criterion a maximum of three points was allocated.

\section{Immunohistochemistry}

Immunohistochemistry was performed as previously described (Wang et al. 2004). Pellets were fixed for maximum of 24 hours with $4 \%$ paraformaldehyde, embedded in paraffin and cut in $4 \mathrm{~mm}$ thick sections. After pre-treatment with $1 \mathrm{mg} / \mathrm{ml}$ chondroitinase, histology slides were incubated with primary monoclonal antibodies for collagen type II (II-II6B3, Hybridoma Bank, University of lowa, lowa, USA) for 1 hour. The sections were then incubated with a biotinylated goat anti-mouse secondary antibody for 35 minutes, followed by StreptABCcomplex/AP (StreptABCcomplex/AP, DAKO, Glostrup, Denmark) for 45 minutes. Bound antibodies were revealed with Fuchsin/Naphtol AS-BI substrate (Fuchsin/Naphtol AS-BI substrate, Sigma-Aldrich, Buchs, Switzerland). Positive control comprised human growth plate section, and negative control were slides where the primary antibody was omitted. Pictures were taken as described for histology slides.

\section{Statistical analysis}

Samples were analyzed with the GraphPad software, employing the un-paired Student t-test. Statistical significance was considered for $P$ values $<0.05$. Mixed factors Anova and Bonferroni multiple comparison tests were applied to assess the effect of donor age, source of sera during the expansion phase and the presence of TGF $\beta 1$ in pellet cultures. Statistical significance was considered for $P$ values $<0.05$.

\section{Results}

Effect of different sera and seeding densities on chondrocyte proliferation

To assess the process of attachment and subsequent chondrocyte de-differentiation associated phenotype, cell recovery after seeding and changes in cell morphology were monitored. Upon isolation, chondrocytes from five horses (mean $=4.4$ years) were allowed to attach in media containing $10 \%$ FCS, $10 \%$ FES or $10 \%$ AES for 48 hours. The percentage of recovered cells was $77.5 \pm 12.4$ (mean \pm SEM) for

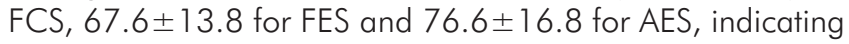
similar adhesion in all tested sources of sera (FCS, FES and AES). Chondrocyte morphology also changed independently of the source of sera in the medium: within the first four days cells appeared small and round-shaped, in accordance with their still differentiated state (Figure 1 A, C, E). Over the next few days, regardless of the source of sera, cells started to elongate and acquired more fibroblast-like shape, a hallmark of the de-differentiation process (Figure 1 B, D, F). These data indicated that the commercially produced types of sera in the medium had no influence on the initial cell attachment and resulted in identical changes in cell morphology in monolayer culture.

The potential effect of low and high seeding density on chondrocyte proliferation rates was analyzed next. Cells were cultured at low - 3'333/ $\mathrm{cm}^{2}$, and high - 10'000 cells $/ \mathrm{cm}^{2}$ density for 40 days in FCS, FES and AES and cumulative population doublings (PD) were calculated for each donor. Obtained data demonstrated that chondrocytes proliferated at the same rates independently of the serum type used (FCS, FES or AES) (Figure 2). The seeding density however, greatly influenced cell proliferation rates. The difference was obvious already after 20 days in culture where cells under low seeding density regime proliferated with cumulative PD of 4.5 compared to 3.22 at high densities $(p<0.01)$. The difference became even more pronounced after 40 days where cumulative PD for low density reached 11 compared to 7.5 for high density $(p<0.001)$. To assess whether cells at higher density decreased their proliferation rates due to saturated cell densities, confluence expressed as cells $/ \mathrm{cm}^{2}$ were calculated at each harvesting step. While the average cell density was significantly higher $(\mathrm{P}<0.05)$ for high seeding density cultures ( $m e a n=43^{\prime} 250 \pm 2^{\prime} 900$ ) compared to low seeding density cultures (mean $=34^{\prime} 740 \pm 1^{\prime} 520$ ), the maximum cells harvested was 105'000 cells $/ \mathrm{cm}^{2}$, suggesting that cells on average were not contact inhibited under either seeding condition. In summary, equine chondrocytes efficiently attached, underwent typical morphological changes associated with the process of de-differentiation under monolayer culturing condi- 
tions, and proliferated with the same efficiency in the different sources of sera. Importantly, lower cell seeding density allowed for higher proliferation rates in all tested sources of sera, but had no impact on the cell morphology.
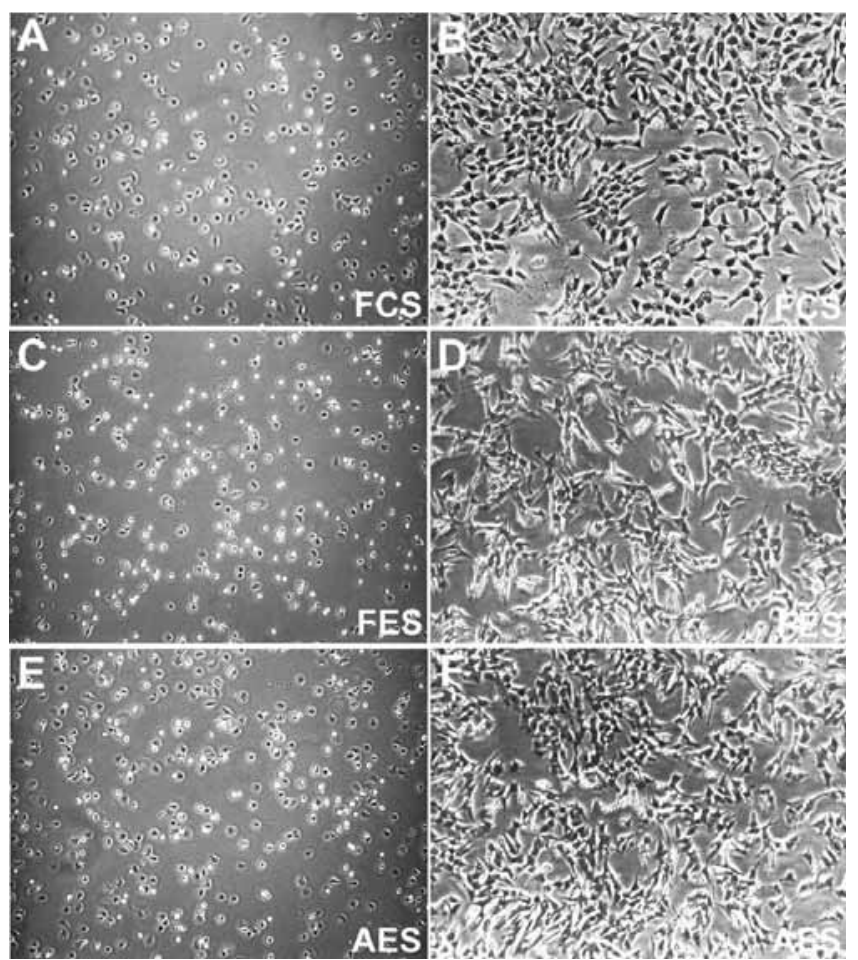

Fig 1 The source of sera, FCS, FES or AES in medium has no effect on chondrocyte attachment and morphology changes during the monolayer culture. Chondrocytes were isolated from the fetlock-joint cartilage of five young horses (mean age $=4.4$ years), seeded at the density of $10^{\prime} 000$ cells $/ \mathrm{cm}^{2}$ and expanded in media containing $10 \%$ FCS, $10 \%$ FES or $10 \%$ AES. Cell attachment and subsequent morphological changes were monitored after $4(A, C, E)$ and 9 days $(B$, $D, F)$. Pictures are representative of chondrocytes from five horses. Magnification 10x.

Die Serumquelle, FCS, FES oder AES im Medium hat keinen Einfluss auf das Anheften und die Veränderung der Morphologie während der Monolayerkultur. Chondrozyten wurden aus Fesselgelenken von 5 Pferden (mittleres Alter $=4.4$ Jahre) isolient, in einer Dichte von $10^{\prime} 000 \mathrm{cell} / \mathrm{s} / \mathrm{cm}^{2}$ ausgesät und in Medium mit 10\% FCS, 10\% FES oder 10\% AES vermehrt. Anschließend wurde die Anheftung und die Veränderung der Morphologie nach 4 ( $A, C, E)$ und nach 9 Tagen $(B$, $D, F)$ beobachted. Die Bilder sind repräsentativ für die Chondrozyten von allen 5 Pferden. Vergrößeruung 10x

The effects of autologous serum and donors age on cell attachment and proliferation

Chondrocytes were isolated from 5 horses of two different age groups - young horses $(n=3$, mean age $=8.6$ years) and old horses ( $n=2$, mean age $=19$ years) to investigate potential influence of age on chondrocytes proliferation and re-differentiation capacities in different sources of sera. The cells were allowed to attach and proliferate in media containing FCS, FES, AES or autologous serum prepared from each horse. While chondrocytes attached equally well in FCS, FES and AES as previously shown (Figure 1), attachment in the autologous sera was dramatically impaired (Figure 3 and data not shown). Moreover, cell adhesion in autologous serum from young horses was more efficient compared to cell adhesion in autologous serum from old horses. To discriminate whether the reason for poor attachment was due to the serum and/or chondrocyte adhesion capacities, both potentially affected by age, cross-cultures were performed combining freshly isolated cells with different sources of sera. The effect of sera on adhesion was evaluated 48 hours after seeding (Figure 3a) and after subsequent 7 days expansion (Figure $3 \mathrm{~b}$ ). Cells from young horse when combined with autologous serum adhered more efficiently (Figure 3a A) compared to the same cells when combined with serum from an old horse (Figure $3 a$ C) yet less efficiently in comparison to FCS (Figure 3a E), suggesting that the source of serum plays an important role for chondrocyte attachment. In comparison, cells from old horse

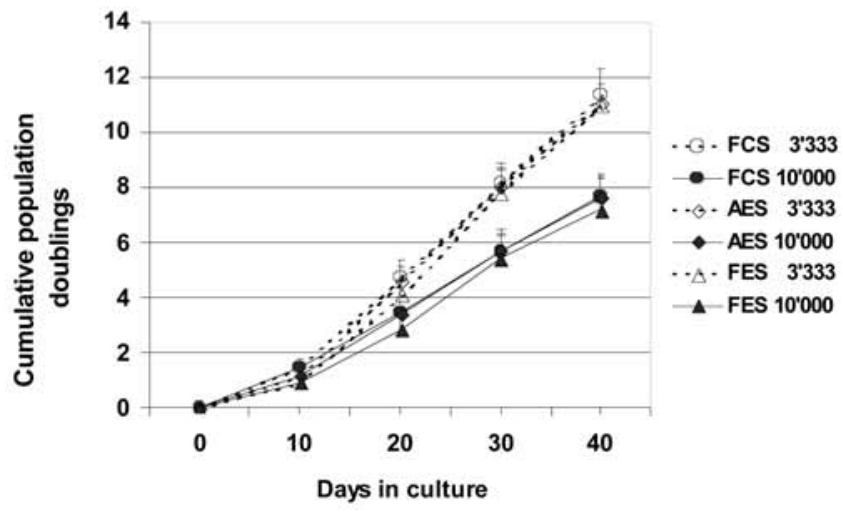

Fig 2 Low chondrocyte seeding densities allow for higher proliferation rates. Chondrocytes from five young horses (mean age $=4.4$ years) were isolated and seeded at 10'000 cells $/ \mathrm{cm}^{2}$ in different sera - FCS, FES and AES. Two days later chondrocytes were harvested and re-seeded at a low $-3^{\prime} 333 / \mathrm{cm}^{2}$, and high $-10^{\prime} 000 \mathrm{cells} / \mathrm{cm}^{2}$ seeding densities and cultured in monolayer for 40 days. At 10, 20, and 30 days cells were trypsinized, counted and re-seeded at low and high seeding densities. Cell proliferation rates in each serum condition were determined by calculating population doublings (PDs) at each passage. Expansion rates were determined by cumulative population doublings $(\mathrm{PD})$ according to $\mathrm{PD}=\log (\mathrm{N} / \mathrm{NO} \times 3.33)$, where $\mathrm{N}$ represents the number of cells at the end and $\mathrm{NO}$ number of cells at the beginning of culture. The results represent mean values \pm SEM. Star indicates $P$ values $<0.01$, and double star indicates $P$ values $<0.001$.

Tiefe Aussaatdichten von Knorpelzellen erlauben eine höhere Proliferationsrate. Chondrozyten von fünf jungen Pferden (mittleres Alter $=$ 4.4 Jahre) wurden aus den Fesselgelenken isoliert und in einer Dichte von $10^{\prime} 000 \mathrm{cells} / \mathrm{cm}^{2}$ in den verschiednen Seren - FCS, FES und AES ausgesät. Zwei Tage später wurden die Zellen geerntet und in tiefer - 3'333/ $\mathrm{cm}^{2}$ und in hoher - $10^{\prime} 000 \mathrm{cells} / \mathrm{cm}^{2}$ Aussaatdichte erneut ausgesät. So wurden die Zellen für 40 Tage in Monolayer kultiviert. Am 10, 20, und 30 Tag wurden die Zellen trypsinisiert, gezählt und wieder ausgesät in tiefe - und hohe Aussaatdichte. Die Zellproliferationsrate in jedem Serum wurden durch Berechnung der Populationsverdoppelung (PDs) in jeder Passage ermittelt. Die Vermehrungsrate wurde durch die kumulative Populationsverdoppelung (PD) ermittelt, gemäß $P D=\log (N / N O x 3.33)$, wobei N die Anzahl der Zellen am Ende und NO die Anzahl der Zellen am Anfang der Kultivierung repräsentieren. Die Resultate zeigen Mittelwerte und \pm Standardabweichungen vom Mittelwert. Der Stern beschreibt P-Werte $<0.01$, und der doppelte Stern beschreibt P-Werte $<0.001$

while failing to attach in autologous serum (Figure 3a B), did attach when combined with the serum from young horse (Figure $3 a \mathrm{D}$ ) and even more efficiently attached in FCS (Figu- 
re $3 a$ F). These data indicate that aged cells attachment could be partially rescued with the appropriate sera possibly through the retention of at least some responsiveness to growth/adhesion factors. Additionally, the presence of factors/binding molecules in the serum influencing cell attachment is also affected by age. The combination of both factors,

\section{Fig $3 a$}
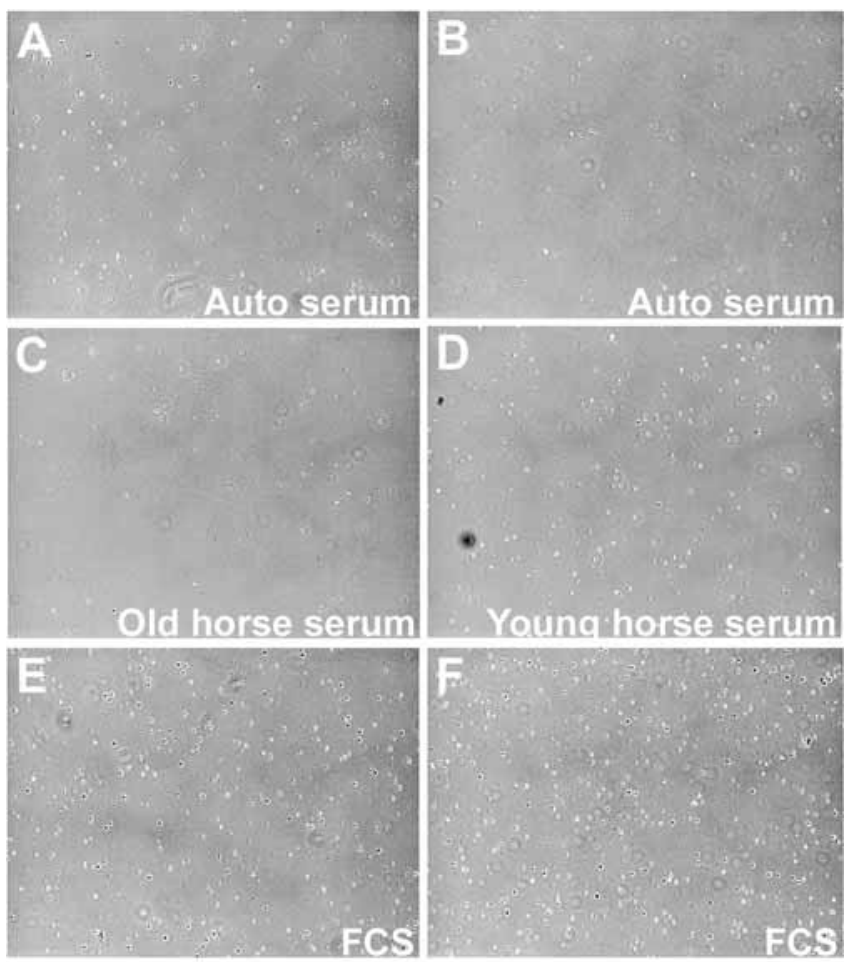

Young horse cells

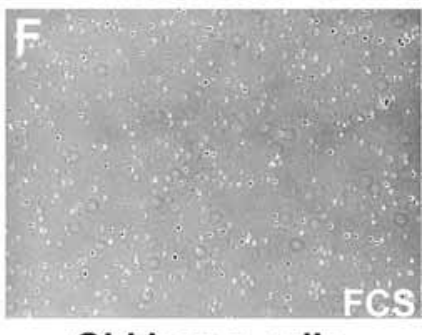

\section{Fig $3 b$}
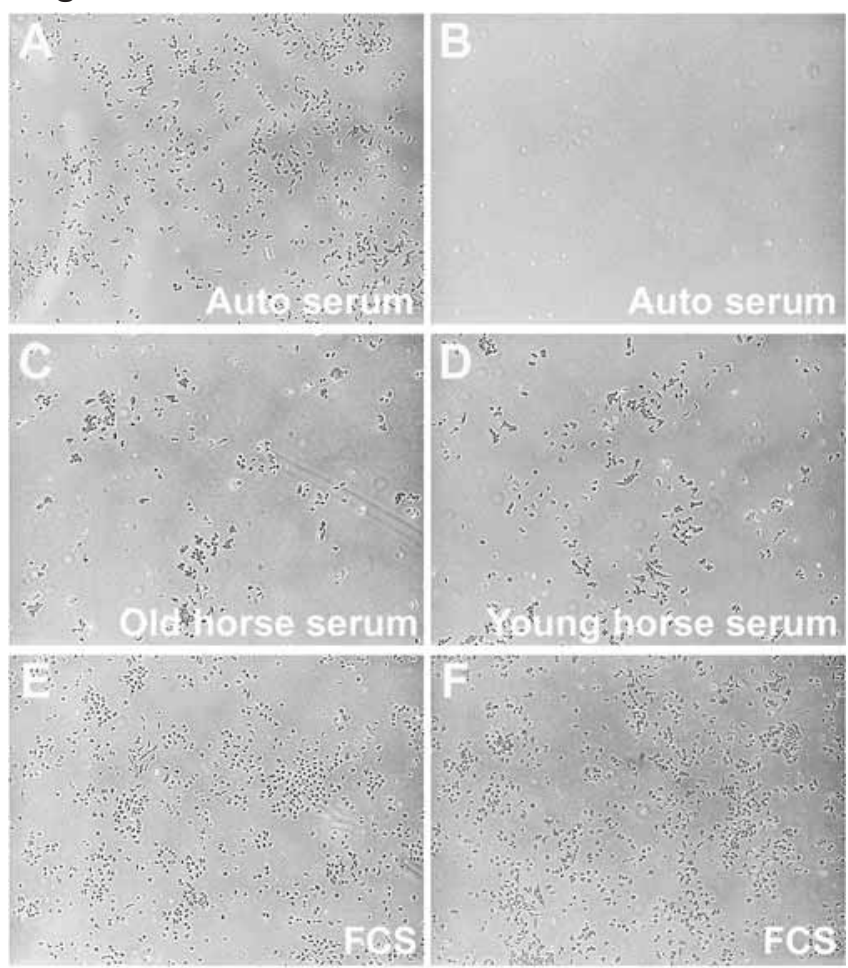

Young horse cells

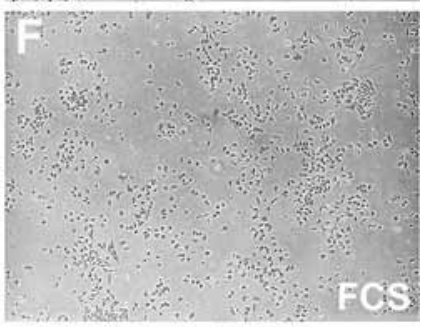

Old horse cells
Fig $3 a$ and $b$ Chondrocytes attach poorly in the autologous serum. Cross-culture experiments were performed combining autologous sera and chondrocytes from young horses (mean age $=8.6$ years) and old horses (mean age $=19$ years). Chondrocytes from young donors seeded at 10'000 cells $/ \mathrm{cm}^{2}$ were incubated for 2 days (a) and 7 days (b)with either autologous serum (A), serum from old horse (C) or FCS (E). Chondrocytes from old donors (10'000 cells $\left./ \mathrm{cm}^{2}\right)$ were incubated for 2 days (a) and 7 days (b) in either autologous serum (B), serum from young donor (D) or FCS (F). Pictures are representative of three independent cross-culture experiments. Magnification 10x.

Chondrozyten heften schlecht an in autologem Serum. Es wurden Kreuzkulturexperimente durchgeführt, wobei autologes Serum mit Chondrozyten von jungen Pferden (mittleres Alter $=8.6$ Jahre) und von alten Pferden (mittleres Alter $=19$ Jahre) kombiniert wurde. Chondrozyten von jungen Pferden wurden in einer Dichte 10'000 cells $/ \mathrm{cm}^{2}$ ausgesät und während 2 Tagen (a) bzw. 7 Tagen (b) entweder mit autologem Serum (A), mit Serum von alten Pferden (C) oder mit FCS (E) inkubiert. Chondrozyten von alten Pferden (10'000 cells $/ \mathrm{cm}^{2}$ ) wurden während 2 Tagen (a) bzw. 7 Tagen (b) entweder in autologem Serum (B), Serum von jungen Spendern (D) oder mit FCS inkubiert. Vergrößerung 10x.

serum and cells, for adhesion and subsequent proliferation, was reflected in partial rescue of old cells with young serum (Figure $3 b$ D) yet in notorious effect of old serum on young cells (Figure $3 \mathrm{~b} \mathrm{C}$ ). Taken together, these results indicate that chondrocyte adhesion in autologous serum is impaired compared to FCS, FES and AES and that the quality of the serum together with cells responsiveness to growth/adhesion factors decline with age.

Poor chondrocyte attachment in autologous sera, in particular for older donors, could also reflect final cells yields after expansion in monolayer culture. To assess this possibility, chondrocytes from young and old horses were cultured in FCS, FES, AES and autologous serum in monolayer at low seeding density, and final cell yields were determined after 20

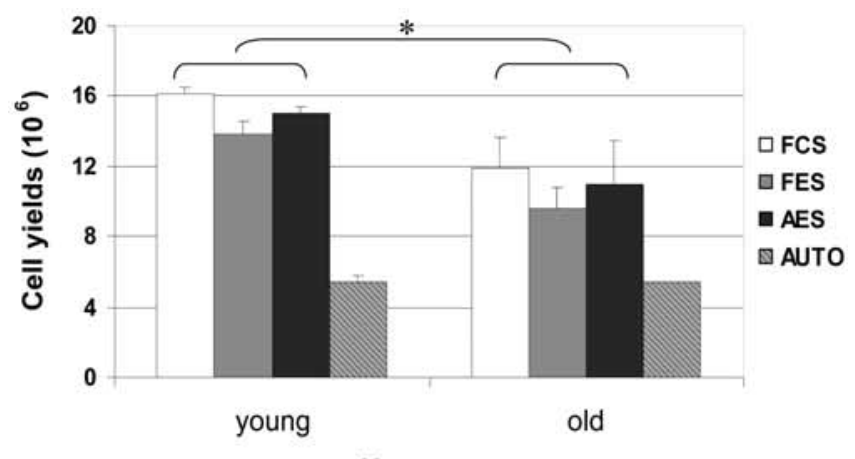

Horse age

Fig 4 Chondrocytes from young horses allow for higher cells yields upon expansion in monolayer compared to chondrocytes from old horses. Chondrocytes from three young horses (mean $=8.6$ years), and two old horses (mean $=19$ years) were cultured at low seeding density in FCS, FES, AES and autologous sera in monolayer for 20 days. Final cell yields are presented as a mean value \pm SEM. Star indicates $P$ values $<0.01$.

Chondrozyten von jungen Pferden erlauben höhere Zellenträge nach der Vermehrung in Monolayer verglichen mit Chondrozyten von alten Pferden. Chondrozyten von drei jungen Pferden (mittleres Alter $=8.6$ Jahre) und zwei alte Pferde (mittleres Alter $=19$ Jahre) wurden in tiefer Aussaatdichte in FCS, FES, AES und autologem Serum während 20 Tagen in Monolayern kultiviert. Die Zellenträge sind als Mittelwerte \pm Standardabweichungen vom Mittelwert dargestellt. Der Stern beschreibt P-Werte $<0.01$. 
days (Figure 4). As expected, due to their poor attachment at each seeding step, significantly lower final yields were obtained from cells cultured in autologous sera in both age groups. On the other hand, cell yields in FCS, FES and AES were comparable within each age group. Importantly, cells from young donors had higher cells yields in FCS, FES and AES compared to cells from old donors $(p<0.01)$ indicating that age has an effect on equine chondrocyte proliferation capacities. Due to the small number of tested animals individual variations could have influenced the results.

The effects of age and source of serum during cell expansion on chondrocyte re-differentiation capacities

The prerequisite for cell-based therapies in cartilage repair is the capacity of chondrocytes to re-differentiate and produce extracellular matrix. Different growth factors have demonstrated the potential to facilitate this process, including the members of TGF $\beta$ family (Mackay et al. 1998, Hanada et al. 2001). To establish optimal re-differentiation conditions chondrocytes from two horses (mean age 5.5) were expanded at low seeding density for 20 days in monolayer in medium containing 10\% FCS and subsequently incubated in pellets for 4 weeks in the defined serum free medium supplemented with different concentrations of $\operatorname{TGF} \beta 1(0,1,5,10 \mathrm{ng} / \mathrm{ml})$. The evaluation of neochondrogenesis performed on Safranin $\bigcirc$ stained histology slides using Berne score (Grogan et al. 2006) indicated that neocartilagenous tissue of similar quality can be obtained with 0 or $5 \mathrm{ng} / \mathrm{ml}$ of TGF $\beta 1$ (data not shown). These conditions for re-differentiation in pellet cultures were used in subsequent experiments.

Re-differentiation capacities of chondrocytes from young and old donors were assessed upon expansion at low seeding density in FCS, FES, AES and autologous serum for 20 days. Formation of neocartilagenous tissue was evaluated through the deposition of early proteoglycans (via Alcian blue staining), late proteoglycans (via Safranin $\bigcirc$ staining), and distribution of collagen type II (via immunostaining), all typical markers for hyaline cartilage tissue (Figures 5 and 6). Chondrocytes from young horses produced early and mature proteoglycans and collagen type II upon expansion in FCS even in the absence of TGF $\beta 1$ (Figure 5 A, C, E). The addition of TGF $\beta 1$ however resulted in more uniform pellet morphology, more mature proteoglycan deposition and formation of lacunae (Figure 5 B, D, F). Chondrocytes expanded in AES demonstrated less chondrogenic potential compared to FCS with no significant effect of TGF $\beta 1$ (Figure $5 \mathrm{M}-\mathrm{R}$ ). Chondrocytes expanded in FES had least chondrogenic potential in the absence of TGF $\beta 1$ compared to the other serum conditions, producing smaller pellets with less mature proteoglycans and very low levels of collagen type II (Figure 5 G, I, K). The addition of TGF $\beta 1$ stimulated these cells to produce larger pellets and synthesize proteoglycans (Figure $5 \mathrm{H}, \mathrm{J}, \mathrm{L}$ ). Chondrocytes expanded in autologous serum produced high amounts of proteoglycans similarly to chondrocytes expanded in FCS with somewhat larger pellets in the absence of TGF $\beta 1$. In the presence of TGF $\beta 1$ pellets contained more mature proteoglycans with formation of lacunae, more distance was evident between individual cells and stronger collagen type II deposition (Figure $5 \mathrm{~T}, \mathrm{~V}, \mathrm{X}$ ).
In older horses the overall chondrogenic potential proved substantially lower in all sources of sera (Figure 6). Pellets were smaller in size, especially in the absence of TGF $\beta 1$, often of irregular morphology with less proteoglycan deposition and virtually no collagen type II detection. Synthesis of mature matrix was detected only in pellets incubated with TGF $\beta 1$ (Figure 6 B, D, F and H, J, L). The best quality neocartilagenous tissue was obtained from cells expanded in FCS and incubated in pellets with TGF $\beta 1$ where the highest amounts of late proteoglycans and visible deposition of collagen type II
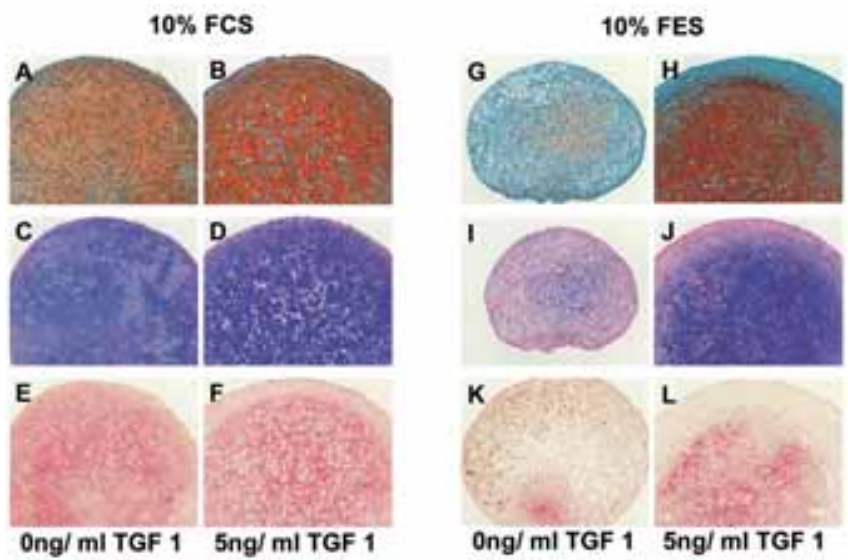

Ong/ml TGF $1 \quad 5 n g / m l$ TGF 1
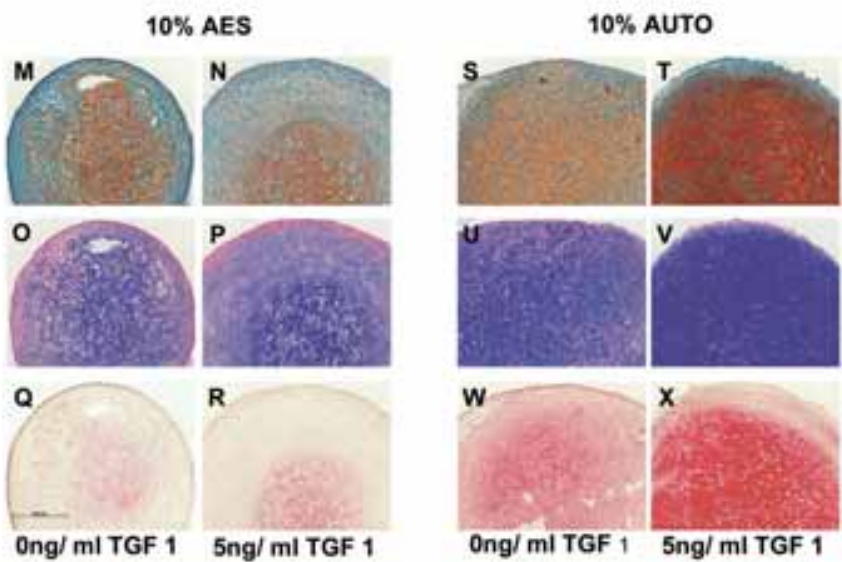

Fig 5 Re-differentiation capacities of chondrocytes from young horses. Chondrocytes were isolated from young donors (mean $=8.6$ years), cultured in monolayer at low seeding density for 20 days in different sera and subsequently incubated in pellets in the defined chondrogenic serum-free medium with or without $5 \mathrm{ng} / \mathrm{ml}$ of TGF $\beta 1$ for 4 weeks. Safranin $\mathrm{O}(\mathrm{A}, \mathrm{B}, \mathrm{G}, \mathrm{H}, \mathrm{M}, \mathrm{N}, \mathrm{S}, \mathrm{T})$ and Alcian blue (C, $D, I, J, O, P, U, V)$ staining depict early and mature proteoglycan deposition, respectively. Immunohistochemistry with anti-collagen type II antibody depicts distribution of collagen type II fibres $(E, F, K$, $L, Q, R, W, X)$. Bar, 100mm. Magnification 20x. The pictures are representative of three donors.

Redifferenzierungskapazität von Chondrozyten junger Pferde. Chondrozyten wurden isoliert von 5 jungen Spender (mittleres Alter $=8.6$ Jahre), diese wurden in den verschiedenen Seren während 20 Tagen in tiefer Aussaatdichte in Monolayer vermehrt und anschließend in Pellets in definiertem, chondrogenen, serumfreien Medium mit- oder ohne $5 \mathrm{ng} / \mathrm{ml}$ of TGF 1 für 4 Wochen inkubiert. Safranin $O(A, B$, $G, H, M, N, S, T)$ und Alcian blau $(C, D, I, J, O, P, U, V)$ Färbung stellen frühe und gereifte Proteoglykan Ablagerungen dar. Immunhistochemie mit Anti-Kollagen II Antkörper stellt die Verteilung der Kollagen Typ // Fasern dar $(E, F, K, L, Q, R, W, X)$. Größenangabe, $100 \mathrm{~mm}$. Vergrößerung 20x. Die Bilder sind repräsentative für drei Spender. 
was observed (Figure 6 B, D, F). The evaluation of neocartilagenous tissue formation was further assessed with Berne score (Figure 7). Based on mixed factors Anova tests, chondrocytes from young horses produced pellets with a higher Berne score compared to chondrocytes from old horses $(P<0.05)$. The highest score from young donors was obtained from cells expanded in autologous serum and incubated in pellets with TGF $\beta 1$ (Score=6). However, it was not statistically different compared to cells expanded in FCS, suggesting that cells from younger donors retain their re-differentiation capacities upon expansion in FCS and autologous serum. Cells from old donors demonstrated a tendency for best re-differentiation upon expansion in FCS and incubation with TGF $\beta 1$ in pellets $(S c o r e=4.3)$. These results indicate that while the source of sera and the presence of TGF $\beta 1$ appear to influence chon-
$10 \%$ FCS
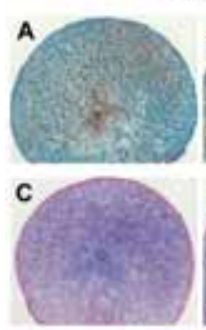

E

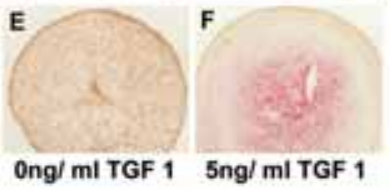

$10 \%$ AES

○

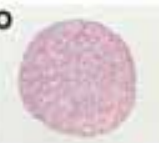

Q

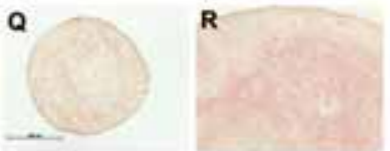

Ong/ml TGF $1 \quad 5 \mathrm{ng} / \mathrm{ml}$ TGF 1

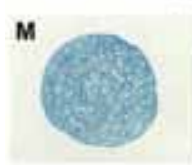

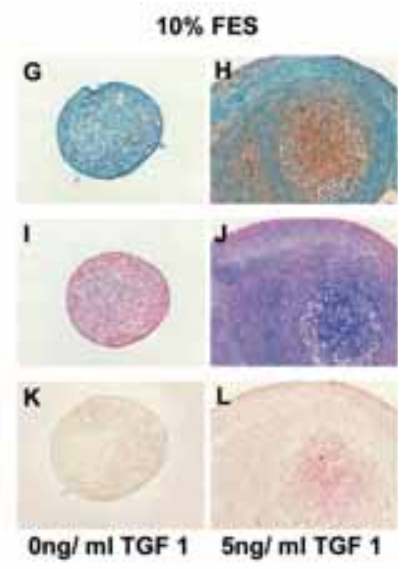

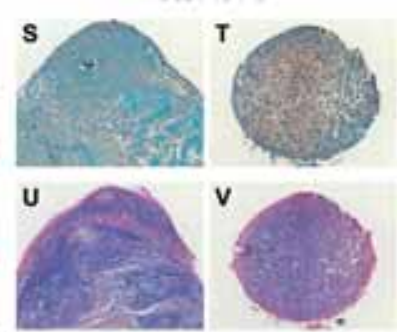

w

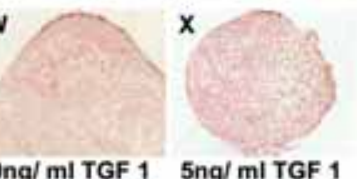

drocyte re-differentiation capacities, donors age clearly has a statistically significant effect.

\section{Discussion}

Understanding the biology and behavior of equine chondrocytes is a prerequisite for the proper design of cell-based treatment for cartilage repair in horses. Chondrocyte expansion with the maintenance of cell chondrogenic re-differentiation capacities is fundamental for the application of cartilage tissue engineering treatments, including $\mathrm{ACl}$. In the present study equine chondrocyte attachment, expansion and re-differentiation capacities were examined. Chondrocytes efficiently adhered and proliferated in medium containing allogenic
A

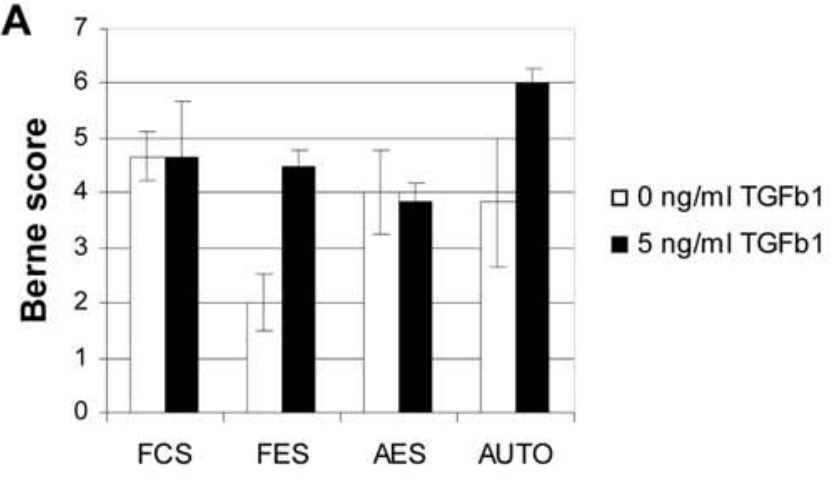

Source of sera

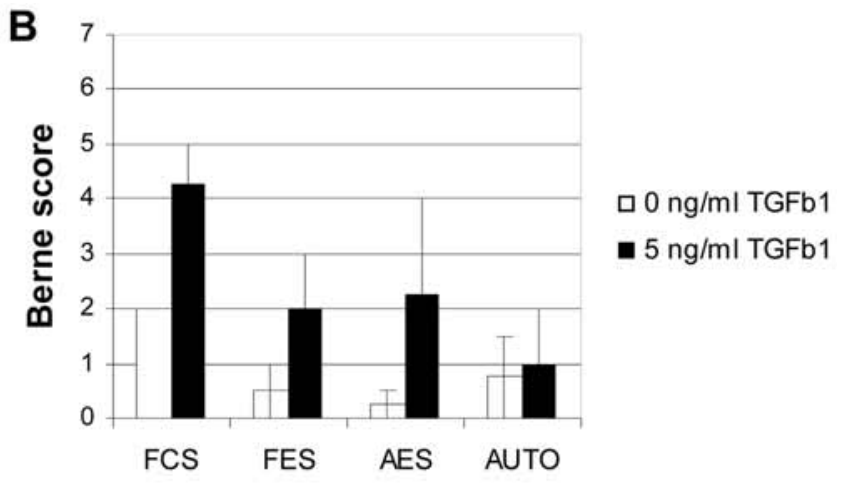

Source of sera

Fig 6 Re-differentiation capacities of chondrocytes from old horses. Chondrocytes were isolated from old donors (mean $=19$ years). Cultures and analysis were as described for Figure 5. Safranin $O(A, B$, $G, H, M, N, S, T)$ and Alcian blue $(C, D, I, J, O, P, U, V)$ staining depict early and mature proteoglycan deposition, respectively. Immunohistochemistry with anti-collagen type II antibody depicts distribution of collagen type II fibres $(E, F, K, L, Q, R, W, X)$. The pictures are representative of two donors.

Redifferenzierungskapazität von alten Pferden. Chondrozyten von alten Spendern wurden isolient (mittleres Alter $=19$ Jahre). Kultivierung und Analysen wurden gleich ausgeführt wie für Bild 5. Safranin $O(A, B, G, H, M, N, S, T)$ und Alcian blau $(C, D, I, J, O, P, U, V)$ Färbung stellen frühe und gereifte Proteoglykan-Ablagerungen dar. Immunhistochemie mit Anti-Kollagen II Antkörper stellt die Verteilung der Kollagen Typ II Fasern dar (E, F, K, L, Q, R, W, X). Die Bilder sind repräsentativ für zwei Spender.

Fig 7A and B Neocartilagenous tissue formation from chondrocytes expanded in different sources of sera is age dependent. Chondrocytes from young donors (A) or old donors (B) were cultured in monolayer $\left(3^{\prime} 333\right.$ cells $\left./ \mathrm{cm}^{2}\right)$ for 20 days in FCS, FES, AES and autologous sera. Pellet cultures were incubated in the defined chondrogenic serum-free medium with or without $5 \mathrm{ng} / \mathrm{ml}$ of TGF $\beta 1$ for 4 weeks. Histology slides were stained with Safranin $\bigcirc$ and evaluated according to the Berne score for neocartilagenous tissue formation. Die Bildung von nevem Knorpelgewebe aus Chondrozyten, vermehrt in unterschiedlichen Seren, ist altersabhängig. Chondrozyten von jungen Spendern (A) oder alten Spendern (B) wurden während 20 Tagen in Monlayern (3.333 Zellen/ $\mathrm{cm}^{2}$ ) in FCS, FES, AES und autologem Serum kulitiviert. Pelletkulturen wurden in definiertem, chondrogenen, serumfreien Medium, mit oder ohne $5 \mathrm{ng} / \mathrm{ml}$ of TGF 7 , während 4 Wochen inkubiert. Histologieschnitte wurden mit Safranin O gefärbt und mit Hilfe des Berne score wurde das neugebildete Knorpelgewebe beurteilt. 
FES, allogenic AES or xenogenic FCS. However, poor chondrocyte attachment in autologous sera at each passage resulted in lower final cell yields compared to the other sera tested. Development of serum free or autologous serum culturing systems for cell expansion in tissue engineering aims to circumvent the problem of disease transmission and immunogenic reaction (Heng et al. 2004, Heiskanen et al. 2007). Several studies have demonstrated beneficial effect of growth factor addition to the serum-free expansion medium for the proliferation and maintenance of the chondrogenic phenotype (Mandl et al. 2002, Malpeli et al. 2004), even overcoming the age-related differences (Giannoni et al. 2005). Although promising, the need for exogenously added growth factors remains the disadvantage of the serum-free approach. Autologous serum represents another alternative to FCS for cell expansion. Studies have demonstrated the possibility to replace FCS for expansion of human mesenchymal stem cells (Stute et al. 2004, Shahdadfar et al. 2005). In human chondrocytes recent data have demonstrated higher proliferation rates of articular and auricular chondrocytes in autologous and allogenic human serum in comparison to FCS (Tallheden et al. 2005, Yanaga et al. 2006). Equine chondrocyte expansion in autologous serum has been successfully employed for the $\mathrm{ACl}$ treatment (Litzke et al. 2004). However, no comparison to FCS has been established. Our data indicate less efficient chondrocyte expansion in autologous serum compared to allogenic AES and FES or xenogenic FCS due to the pronounced difficulty in cell attachment at each passage. The impaired adhesion in autologous serum could be attributed to the fact that the sera derived from stunned horses which were transported for slaughtering and thus experienced stress: during the procedures for optimizing serum preparation, sera were prepared from living horses within the horse clinic (unstressed), and tested on homologous chondrocytes. No significant differences in cell adhesion and comparable proliferation rates were observed between chondrocytes in FCS or in individual homologous sera from living horses (data not shown), suggesting that trauma-related transport and stunning may have caused the release of stress factors, including catecholamines, which could alter expression of adhesion molecules in vitro, as suggested in other cell types (Shepard 2003). The problem of attachment however, had no effect on young chondrocytes re-differentiation capacities, suggesting that factors important for adhesion differ from those required for chondrogenenic capacities.

The age of horses also affected chondrocyte attachment in autologous serum. Our data suggest that not only chondrocyte responsiveness to serum factors declines with age, but that the presence of growth factors and extracelular matrix molecules facilitating adhesion decreases with age. Age-related changes in chondrocyte biology are well documented. Chondrocytes number in cartilage significantly decrease with advancing age (Bobacz et al. 2004), their proliferative response to serum changes and declines (Guerne et al. 1995, Barbero et al. 2004), cells senesce and shorten their telomere length (Martin and Buckwalter 2003). In horses, proteoglycan synthesis and chondrocyte responsiveness to TGF $\beta 1$ steadily decreases with increasing age (lqbal et al. 2000].

Seeding density had an important effect on chondrocyte proliferation in FCS, FES and AES. Cells seeded at low seeding densities proliferated faster compared to chondrocytes seeded at high seeding density. The long accepted postulation has been that low seeding densities allow for higher proliferation rates but lead to more pronounced de-differentiation (Holtzer et al. 1960, Watt 1988). Several mechanisms have been suggested to explain this phenomenon, including more population doublings before confluence is reached and changes in cytoskeletal microfilament organization (Lim et al. 2000, Mandl et al. 2004). However, recent studies using human auricular and nasal septal chondrocytes have demonstrated that low seeding density in monolayer cultures resulted in fewer rounds of passaging (exposure to trypsin) to obtain similar cell yields, and preserved chondrocyte chondrogenic potential (Mandl et al. 2004, Hicks et al. 2005). Our data showed that chondrocytes seeded at high density reach the average cell density of $43^{\prime} 250$ cells $/ \mathrm{cm}^{2}$ at the time of harvest. This value is far below the maximum density of $105^{\prime} 000$ cells $/ \mathrm{cm}^{2}$ observed in the high density cultures, indicating that cells at $43^{\prime} 250 \mathrm{cells} / \mathrm{cm}^{2}$ have not reached saturation density, and suggesting that contact inhibition is an unlikely cause for lower cell yields observed. Faster proliferation at lower densities has also been reported for human MSC (Sekiya et al. 2002, Both et al. 2006). Possible explanation includes involvement of Wnt signaling (Gregory et al. 2003, De Boer et al. 2004). The firm conclusion has however, not been reached, most probably due to several different factors contributing to this phenomenon. One could hypothesize that similar mechanisms may be implicated in equine chondrocytes. Importantly, the capacity of equine articular chondrocytes to re-differentiate upon expansion at low seeding densities in FCS, FES, AES and autologous sera indicates preservation of their chondrogenic potential. Such expansion regime would allow initiating cell expansion with lower cell numbers and hence smaller biopsies.

High cell density three-dimensional culture is a necessary requirement for in vitro cartilage formation. Furthermore, chondrogenesis can be facilitated by the addition of exogenous growth factors including TGF $\beta$, BMP-2, and IGF-1 (Kuznetsov et al. 2001, Heng et al. 2004). TGF $\beta$ and IGF-1 have also demonstrated positive chondrogenic effect on equine chondrocytes (Fortier et al. 1997, Fortier et al. 2002). In this study chondrocyte re-differentiation capacities were influenced by the source of sera during the expansion phase and the age of donors. The presence of TGF $\beta 1$ during the re-differentiation phase proved less critical for chondrocytes from young donors which had retained their re-differentiation capacities even in the absence of TGF $\beta 1$, while cells from old horses required the presence of TGF $\beta 1$. Importantly, while chondrocytes from young donors re-differentiated efficiently upon expansion in FCS or autologous serum, expansion of chondrocytes from old donors required FCS.

In summary, our data demonstrate that equine chondrocytes can be isolated from smaller biopsies and expanded at low seeding densities to allow higher yields. Importantly, the age of the horse has a profound effect on chondrocyte behavior and emphasizes the necessity to understand individual equine chondrocyte requirements to successfully design cell based treatment of cartilage defects. Our data indicate that for cells from young donors autologous serum could replace FCS thereby avoiding possible exposure to infections and inflammatory reactions. In contrast, cells from older horses although with obvious impaired proliferation and re-differentiation capacities, could still be employed providing that they are 
expanded in FCS and re-differentiated in the presence of TGF $\beta 1$. More detailed studies on larger cohorts of animals are needed to determine the age threshold.

\section{Abbreviations}

FCS fetal calf serum

FES fetal equine serum

AES adult equine serum

$\mathrm{ACl}$ autologous chondrocyte implantation

\section{Acknowledgements}

This work was supported by an educational grant from Allevia $A G$, Switzerland.

The authors would like to thank Verena Winkelmann, Chantal Pauli, Kathrin Boschung and Simon Herren for excellent technical assistance.

\section{References}

Barbero A., S. Grogan, D. Schafer, M. Heberer, P. Mainil-Varlet and I. Martin (2004) Age related changes in human articular chondrocyte yield, proliferation and post-expansion chondrogenic capacity. Osteoarthritis Cartilage 12, 476-484

Bobacz K., L. Erlacher, J. Smolen, A. Soleiman and W. B. Graninger (2004) Chondrocyte number and proteoglycan synthesis in the aging and osteoarthritic human articular cartilage. Ann. Rheum. Dis. 63, 1618-1622

Both S. K., A. J. Muijsenberg, C. A. Blitterswijk, J. D. Boer and J. D. Bruijn (2007) A Rapid and Efficient Method for Expansion of Human Mesenchymal Stem Cells. Tissue Eng. 13, 3-9

Brehm W., C. Werren and P. Mainil-Varlet (2007) Production of very large sized scaffold-free engineered cartilage constructs from adult equine donor - a basis for therapeutic and experimental application in horses. Pferdeheilkunde 23, 111-117

Brittberg M., A. Lindahl, A. Nilsson, C. Ohlsson, O. Isaksson and L. Peterson (1994) Treatment of deep cartilage defects in the knee with autologous chondrocyte transplantation. N. Engl. J. Med. 331, 889-895

Cremer M. A., E. F. Rosloniec and A. H. Kang (1998) The cartilage collagens: a review of their structure, organization, and role in the pathogenesis of experimental arthritis in animals and in human rheumatic disease. J. Mol. Med. 76, 275-288

De Boer J., H. J. Wang and C. Van Blitterswijk (2004) Effects of Wnt signaling on proliferation and differentiation of human mesenchymal stem cells. Tissue Eng. 10, 393-401

Dedrick V. (1997) Determining the safety of medical devices containing animal tissues: the new European standards. J. Regul. Affairs Prof. Soc. 2, 20

Diaz-Romero J., J. P. Gaillard, S. P. Grogan, D. Nesic, T. Trub and P. Mainil-Varlet (2005) Immunophenotypic analysis of human articular chondrocytes: changes in surface markers associated with cell expansion in monolayer culture. J. Cell. Physiol. 202, 731-742

Fortier L. A., H. O. Mohammed, G. Lust and A. J. Nixon (2002) Insulin-like growth factor-I enhances cell-based repair of articular cartilage. J. Bone Joint Surg. Br. 84, 276-288

Fortier L. A., A. J. Nixon, H. O. Mohammed and G. Lust (1997) Altered biological activity of equine chondrocytes cultured in a threedimensional fibrin matrix and supplemented with transforming growth factor beta-1. Am. J. Vet. Res. 58, 66-70
Frisbie D. D., M. W. Cross and C. W. Mcllwraith (2006) A comparative study of articular cartilage thickness in the stifle of animal species used in human pre-clinical studies compared to articular cartilage thickness in the human knee. Vet. Comp. Orthop. Traumatol. 19,142-146

Giannoni P., A. Pagano, E. Maggi, R. Arbico, N. Randazzo, M. Grandizio, R. Cancedda and B. Dozin (2005) Autologous chondrocyte implantation $(\mathrm{ACl})$ for aged patients: development of the proper cell expansion conditions for possible therapeutic applications. Osteoarthritis Cartilage 13, 589-600

Gregory C. A., H. Singh, A. S. Perry and D. J. Prockop (2003) The Wnt signaling inhibitor dickkopf- 1 is required for reentry into the cell cycle of human adult stem cells from bone marrow. J. Biol. Chem. 278(, 28067-28078

Grogan S. P., A. Barbero, V. Winkelmann, F. Rieser, J. S. Fitzsimmons, S. O'Driscoll, I. Martin and P. Mainil-Varlet (2006) Visual histological grading system for the evaluation of in vitro-generated neocartilage. Tissue Eng. 12, 2141-2149

Guerne P. A., F. Blanco, A. Kaelin, A. Desgeorges and M. Lotz (1995) Growth factor responsiveness of human articular chondrocytes in aging and development. Arthritis Rheum. 38, 960-968

Hanada K., L. A. Solchaga, A. I. Caplan, T. M. Hering, V. M. Goldberg, J. U. Yoo and B. Johnstone (2001) BMP-2 induction and TGF-beta 1 modulation of rat periosteal cell chondrogenesis. J. Cell Biochem. 81, 284-294

Heiskanen A., T. Satomaa, S. Tiitinen, A. Laitinen, S. Mannelin, U. Impola, M. Mikkola, C. Olsson, H. Miller-Podraza, M. Blomqvist, A. Olonen, H. Salo, P. Lehenkari, T. Tuuri, T. Otonkoski, J. Natunen, J. Saarinen and J. Laine (2007) N-glycolylneuraminic acid xenoantigen contamination of human embryonic and mesenchymal stem cells is substantially reversible. Stem Cells 25, 197-202

Heng B. C., T. Cao and E. H. Lee (2004) Directing stem cell differentiation into the chondrogenic lineage in vitro. Stem Cells 22, $1152-1167$

Hicks D. L., A. B. Sage, B. L. Schumacher, R. L. Sah and D. Watson (2005) Growth and phenotype of low-density nasal septal chondrocyte monolayers. Otolaryngol Head Neck Surg 133, 417-422

Holtzer H., J. Abbott, J. Lash and S. Holtzer (1960) The Loss of Phenotypic Traits by Differentiated Cells in Vitro, I. Dedifferentiation of Cartilage Cells. Proc. Natl. Acad. Sci. USA 46, 1533-1542

labal J., J. Dudhia, J. L. Bird and M. T. Bayliss (2000) Age-related effects of TGF-beta on proteoglycan synthesis in equine articular cartilage. Biochem. Biophys. Res. Commun. 274, 467-471

Klein R. and L. J. Dumble (1993) Transmission of Creutzfeldt-Jakob disease by blood transfusion. Lancet 341, 768

Koerner J., D. Nesic, J. D. Romero, W. Brehm, P. Mainil-Varlet and S. P. Grogan (2006) Equine peripheral blood-derived progenitors in comparison to bone marrow-derived mesenchymal stem cells. Stem Cells 24, 1613-1619

Kuznetsov S. A., M. H. Mankani, S. Gronthos, K. Satomura, P. Bianco and P. G. Robey (2001) Circulating skeletal stem cells. J. Cell Biol. 153, 1133-1140

Lim Y. B., S. S. Kang, T. K. Park, Y. S. Lee, J. S. Chun and J. K. Sonn (2000) Disruption of actin cytoskeleton induces chondrogenesis of mesenchymal cells by activating protein kinase C-alpha signaling. Biochem. Biophys. Res. Commun. 273, 609-613

Litzke L. E., E. Wagner, W. Baumgaertner, U. Hetzel, O. JosimovicAlasevic and J. Libera (2004): Repair of extensive articular cartilage defects in horses by autologous chondrocyte transplantation. Ann. Biomed. Eng. 32, 57-69

Mackay A. M., S. C. Beck, J. M. Murphy, F. P. Barry, C. O. Chichester and M. F. Pittenger (1998) Chondrogenic differentiation of cultured human mesenchymal stem cells from marrow. Tissue Eng. 4, 415-428

Malpeli M., N. Randazzo, R. Cancedda and B. Dozin (2004) Serumfree growth medium sustains commitment of human articular chondrocyte through maintenance of Sox9 expression. Tissue Eng. 10, 145-155

Mandl E. W., S. W. van der Veen, J. A. Verhaar and G. J. van Osch (2002) Serum-free medium supplemented with high-concentration FGF2 for cell expansion culture of human ear chondrocytes promotes redifferentiation capacity. Tissue Eng. 8, 573-580 
Mandl E. W., S. W. van der Veen, J. A. Verhaar and G. J. van Osch (2004) Multiplication of human chondrocytes with low seeding densities accelerates cell yield without losing redifferentiation capacity. Tissue Eng. 10, 109-118

Marlovits S., P. Zeller, P. Singer, C. Resinger and V. Vecsei (2006) Cartilage repair: generations of autologous chondrocyte transplantation. Eur. J. Radiol. 57, 24-31

Martin J. A. and J. A. Buckwalter (2003) The role of chondrocyte senescence in the pathogenesis of osteoarthritis and in limiting cartilage repair. J. Bone Joint Surg. Am. 85-A Suppl 2, 106-1 10

Mcllwraith C. W., J. V. Yovich and G. S. Martin (1987) Arthroscopic surgery for the treatment of osteochondral chip fractures in the equine carpus. J. Am. Vet. Med. Assoc. 191, 531-540

Mendler M., S. G. Eich-Bender, L. Vaughan, K. H. Winterhalter and P. Bruckner (1989) Cartilage contains mixed fibrils of collagen types II, IX, and XI. J. Cell Biol. 108, 191-197.

Reinholz G. G., L. Lu, D. B. Saris, M. J. Yaszemski and S. W. O'Driscoll $(2004)$ Animal models for cartilage reconstruction. Biomaterials 25, 1511-1521

Schnabel M., S. Marlovits, G. Eckhoff, I. Fichtel, L. Gotzen, V. Vecsei and J. Schlegel (2002) Dedifferentiation-associated changes in morphology and gene expression in primary human articular chondrocytes in cell culture. Osteoarthritis Cartilage 10, 62-70.

Sekiya I., B. L. Larson, J. R. Smith, R. Pochampally, J. G. Cui and D. J. Prockop (2002) Expansion of human adult stem cells from bone marrow stroma: conditions that maximize the yields of early progenitors and evaluate their quality. Stem Cells 20, 530-54 1

Selvaggi T. A., R. E. Walker and T. A. Fleisher (1997) Development of antibodies to fetal calf serum with arthus-like reactions in human immunodeficiency virus-infected patients given syngeneic lymphocyte infusions. Blood 89, 776-779

Shahdadfar A., K. Fronsdal, T. Haug, F. P. Reinholt and J. E. Brinchmann (2005) In vitro expansion of human mesenchymal stem cells: choice of serum is a determinant of cell proliferation, differentiation, gene expression, and transcriptome stability. Stem Cells 23, 1357-1366

Shephard R. J. (2003) Adhesion molecules, catecholamines and leucocyte redistribution during and following exercise. Sports Med. 33, 261-284

Stute N., K. Holtz, M. Bubenheim, C. Lange, F. Blake and A. R. Zan$\operatorname{der}$ (2004) Autologous serum for isolation and expansion of human mesenchymal stem cells for clinical use. Exp. Hematol. $32,1212-1225$

Tallheden T., J. van der Lee, C. Brantsing, J. E. Mansson, E. SiogrenJansson and A. Lindahl (2005) Human serum for culture of articular chondrocytes. Cell Transplant 14, 469-479

Ulrich-Vinther M., M. D. Maloney, E. M. Schwarz, R. Rosier and R. J. O'Keefe (2003) Articular cartilage biology. J. Am. Acad. Orthop. Surg. 11, 421-430

Vacanti J. P., R. Langer, J. Upton and J. J. Marler (1998) Transplantation of cells in matrices for tissue regeneration. Adv. Drug. Deliv. Rev. 33, 165-182

Wang X., S. P. Grogan, F. Rieser, V. Winkelmann, V. Maquet, M. L. Berge and P. Mainil-Varlet (2004) Tissue engineering of biphasic cartilage constructs using various biodegradable scaffolds: an in vitro study. Biomaterials 25, 3681-3688

Watt F. M. (1988) Effect of seeding density on stability of the differentiated phenotype of pig articular chondrocytes in culture. J. Cell Sci. 89 (P+ 3), 373-378

Yanaga H., K. Yanaga, K. Imai, M. Koga, C. Soejima and K. Ohmori (2006) Clinical application of cultured autologous human auricular chondrocytes with autologous serum for craniofacial or nasal augmentation and repair. Plast. Reconstr. Surg. 117, 2019 2030; discussion 2031-2012

Dobrila Nesic, PhD

Osteoarticular Research Group

Institute of Pathology, University of Bern

Murtenstraße 31, 3010 Bern

Switzerland

dobrila.nesic@pathology.unibe.ch 